\title{
Global linkages among energy, food and water: an economic assessment
}

\author{
Claudia Ringler $^{1} \cdot$ Dirk Willenbockel $^{2} \cdot$ Nicostrato Perez $^{1} \cdot$ Mark Rosegrant $^{1}$. \\ Tingju Zhu ${ }^{1} \cdot$ Nathanial Matthews $^{3}$
}

Published online: 3 March 2016

(C) The Author(s) 2016. This article is published with open access at Springerlink.com

\begin{abstract}
The resolution adopted by the General Assembly of the United Nations on 25 September 2015 is symptomatic of the water-energy-food (WEF) nexus. It postulates goals and related targets for 2030 that include (1) End hunger, achieve food security and improved nutrition, and promote sustainable agriculture (SDG2); (2) Ensure availability and sustainable management of water and sanitation for all (SDG6); and (3) Ensure access to affordable, reliable, sustainable, and modern energy for all (SDG7). There will be tradeoffs between achieving these goals particularly in the wake of changing consumption patterns and rising demands from a growing population expected to reach more than nine billion by 2050 . This paper uses global economic analysis tools to assess the impacts of long-term changes in fossil fuel prices, for example, as a result of a carbon tax under the UNFCCC or in response to new, large findings of fossil energy sources, on water and food outcomes. We find that a fossil fuel tax would not adversely affect food security and could be a boon to global food security if it reduces adverse climate change impacts.
\end{abstract}

Claudia Ringler

c.ringler@cgiar.org

1 International Food Policy Research Institute, $2033 \mathrm{~K}$ Street NW, Washington, DC 20006, USA

2 Institute of Development Studies at the University of Sussex, Brighton BN1 9RE, UK

3 CGIAR Research Program on Water, Land and Ecosystems, 127, Sunil Mawatha, Pelawatte, Battaramulla 10120, Sri Lanka
Keywords Energy price $\cdot$ Water security $\cdot$ Food security

\section{Introduction}

Between 2010 and 2050, the global population is expected to increase by another two billion. Almost all this growth is concentrated in the group of developing countries. The larger population in this region is expected to be wealthier, consume more - and more water-intensive - calories, have increased access to modern energy, and enjoy enhanced access to water supplies. The realization of these benefits assumes, however, that significant advancements can be made in several of the SDGs adopted by UN member states in September 2015 (UN 2015a).

Particularly three of the goals are symptomatic of the water-energy-food (WEF) nexus. These are (1) End hunger, achieve food security and improved nutrition, and promote sustainable agriculture (SDG2); (2) Ensure availability and sustainable management of water and sanitation for all (SDG6); and (3) Ensure access to affordable, reliable, sustainable, and modern energy for all (SDG7). Expected improvements in these three sectors are interlinked and, given growing natural resource scarcity and degradation and political and economic constraints, are unlikely to all be achieved everywhere by 2030 nor by 2050 . Increases in food production require large additional water and energy resources, increased access to modern (renewable) energy depends on the use of increased amounts of water, and full access to safe water supplies will require both more water and more energy to treat this water to safe standards. All of the improvements require political will, significant investment, and institutional capacity.

The interlinkages and trade-offs between water, energy, and food at the global level became apparent as a result of the world food price crisis of 2007/08. This crisis was driven, in part, by 
the generation of energy from food crops (Rosegrant 2008; Rosegrant et al. 2008), contributing to a high correlation coefficient between food and oil price indexes but also by drought in key wheat-producing areas of Australia and Ukraine. Another important determinant of the close linkage between these price indexes is the increased energy intensity of agriculture and the food supply chain, particularly in some rapidly growing developing countries (Ringler et al. 2013).

Future energy price developments and associated food price developments and water outcomes are highly uncertain and depend on the drivers for energy and food price developments. Energy price developments are determined by changes in fossil fuel consumption, which in turn are influenced by changes in global energy demand, uncertainty of future fossil fuel availability, greenhouse gas (GHG) emissions, global warming and related climate policy, and geopolitical maneuvering (IEA, 2012; NREL, 2012). Most previous studies linking energy and food focused on biofuel development as a source of energy affected by and affecting energy or food markets or both, as well as greenhouse gas emissions and land use change (Dodder et al. 2011; Hertel et al. 2010; Hertel et al. 2013). Steinbuks and Hertel (2013) find that changes in long-term energy prices can have large impacts on agricultural land use for both food crops and biofuel stocks as the former respond to changes in fertilizer prices and the latter are directly affected by global energy prices. Gohin and Chantret (2010) simulate a drop in fossil fuel extraction and find that agricultural and energy prices move in opposite direction when real income effects (driven by differential terms-oftrade effects) are taken into account. Thus, they find a negative relationship between world food and energy prices - when energy price increases are not driven by overall economic growth.

In order to improve energy security and reduce GHG emissions from conventional fossil fuels, evidence supports the need to introduce a larger share of alternative energy sources, such as nuclear and renewable energy, into the global energy mix (IEA, 2012). A recent assessment of the International Energy Agency (IEA 2015) of the Intended Nationally Determined Contributions (INDC Scenario) ${ }^{1}$ finds a weakening between global economic output and energy-related GHG. However, currently proposed emission reductions, while significant, are expected to still lead to a global temperature increase of around $2.6^{\circ} \mathrm{C}$ by 2100 . Over the past decade (2000 2010), emissions from fossil fuel combustion and industrial processes were already relatively stable, contributing about $78 \%$ of total GHG emissions.

\footnotetext{
${ }^{1}$ The INDC Scenario of the IEA represents a preliminary assessment of the implications of the submitted INDCs and statements of intended INDC content available at the UNFCCC Secretariat by 14 May 2015 and includes Switzerland, European Union, Norway, Mexico, United States, Gabon, Russia, Liechtenstein and Andorra), accounting for $34 \%$ of global energy-related $\mathrm{CO} 2$ emissions as well as declarations by China and India and others. For countries without information, the policies defined in the New Policies Scenario of WEO-2014 are assumed.
}

Linking a global general equilibrium model with IFPRI's International Model for Policy Analysis of Agricultural Commodities and Trade (IMPACT), this paper assesses the implications of long-term changes in energy prices due to climate policy for water and food outcomes.

\section{Methodology}

The modeling methodology links the global computable general equilibrium (CGE) model GLOBE with IFPRI's IMPACT version 3 (Robinson et al. 2015). IMPACT3 is a modular integrated assessment model, linking information from climate models, crop simulation models, and water models to a global, partial equilibrium, multimarket model centered on the agriculture sector. The multimarket model simulates the operation of national and international markets, solving for production, demand, and prices that equate supply and demand across the globe. IMPACT 3 has been designed to support longer-term scenario analysis through the integration of these multidisciplinary modules to provide researchers and policymakers with a flexible tool to assess and compare the potential effects of changes in biophysical systems, socioeconomic trends, agricultural technologies, and policies. The core multimarket model simulates food supply and demand for 159 countries. Agricultural production is further disaggregated to include 320 food production units (FPUs), which are intersections of river basins and national boundaries, that is, an intersection of 154 river basins with 159 economic regions. The multimarket model simulates 62 agricultural commodity markets, covering all key food as well as key non-food crops, such as cotton. The water models in IMPACT3 include a global hydrology model (IGHM) that simulates snow accumulation and melt and rainfall-runoff processes at 0.5 -degree latitude by 0.5 -degree longitude resolution, a water basin supply and demand model (IWSM) that operates at the FPU level, and the IMPACT crop water allocation and stress model that estimates the impact of water shortages on crop yields, also at the FPU level. These three modules allow for an assessment of climate variability and change on water availability for the agriculture and other sectors, as well as for an assessment of changes in water demand, investment in water storage and irrigation infrastructure, and technological improvements on water and food security. In particular, the IGHM model simulates natural hydrological processes, thus estimating water availability, while the IWSM model simulates human appropriation of surface water and groundwater, considering water infrastructure capacity and policies, based on which we calculated water stress. While IMPACT does not yet have a dedicated energy module, it can simulate the impact of changes in fertilizer prices on food supply and demand. Moreover, changes in energy prices on the demand for hydropower development 
and on groundwater pumping can be simulated as exogenous changes in the modeling framework. Additional details can be found in Robinson et al. (2015).

The global CGE model is an extended recursive-dynamic version of the comparative-static GLOBE model originally developed by McDonald, Thierfelder and Robinson (2007). Apart from the incorporation of capital accumulation, population growth, labor force growth, and technical progress, the extended model features a detailed representation of the technical substitution possibilities in the power sector. The model consists of a set of individual country or region blocs that together provide complete coverage of the global economy and that are linked through international trade and capital flows. Each region bloc represents the whole economy of that region at a sectorally disaggregated level. The economic interactions among producers, consumers, and the government as well as economic transactions with other regions are explicitly captured. Producers in each region combine primary factors (skilled and unskilled labor, physical capital, land, and other natural resources) and intermediate inputs obtained from the same and other production sectors at home and abroad to produce output. The output is sold to domestic households, the domestic government, to domestic producers (for use as intermediate input or as an addition to the productive capital stock), and to the rest of the world. The production process generates factor income in the form of wages, land and natural resource rents, and returns to capital as well as production tax income for the government. The factor income flows to households. Households use their income to pay income taxes, to buy consumer goods, and to save for future consumption. The government receives additional tax revenue from sales taxes including revenue from import duties. Producer and consumer responses to price and income changes are modeled in accordance with microeconomic theory, and the parameters governing these responses to changes in input and output prices are based on available econometric evidence.

The model is calibrated to the GTAP 8.1 database (Narayanan et al. (eds.) 2012), which represents the global economy-wide structure of production, demand, and international trade at a regionally and sectorally disaggregated level for the benchmark year 2007. The version of GLOBE employed in the present study distinguishes 24 commodity groups and production sectors and 15 geographical regions as detailed in Appendix Tables 5 and 6. In the development of a dynamic baseline for the present study, the growth rates of labor-augmenting technical progress by region are calibrated such that the regional baseline GDP growth rates replicate the GDP growth assumed in the IMPACT baseline projections. Moreover, for agricultural commodities, the sectoral total factor productivity parameters are calibrated such that the baseline producer price paths are consistent with the corresponding aggregated IMPACT producer price projections. For applications of earlier GLOBE versions in a food security context, see
Willenbockel (2012) and Government Office for Science (2011).

To assess linkages across the water-energy-food nexus (WEF), we simulate four alternative scenarios that are described in Table 1, all using identical socioeconomic and population growth rates under Shared Socioeconomic Pathway (SSP) 2, a middle-of-the-road scenario, which follows historical trends (O'Neill et al., 2014 and 2015) but with relatively low population and relatively optimistic economic growth rates in several developing country regions compared to the recent past. $^{2}$ Scenario 1 (Base) describes a business-as-usual scenario suggesting that trends in agricultural research and development and trade policy, among others, will continue from the recent past. The scenario thus assumes no changes in the taxation of fossil fuels over the simulation horizon and first-generation biofuel demand evolves according to IMPACT baseline assumptions.

Scenario 2 (HEP) assumes a strong climate agreement at the end of 2015 with a global agreement to reduce fossil fuel use. This scenario is implemented through a gradual, linear phasing-in of additional fossil fuel taxes globally from 2016 onwards up to 2050 on top of baseline sales taxes such that the additional ad valorem tax wedges between producer and user prices reach 70,50 , and $30 \%$ for coal, crude oil, and natural gas, respectively, by 2050 . Changes in fossil fuel use in the electricity sector between HEPCC and BaseCC are shown in Appendix Table 7. The resulting user price increases for the primary fossil fuels and petrol induce substitution effects towards renewable energy sources in production along with investments in more energy-efficient technologies as well as substitution effects towards less energy-intensive goods in final consumption. As a consequence, the demand for fossil fuels drops relative to the baseline and the producer prices for coal, crude oil, and natural gas fall significantly, while the producer prices of refined petrol rise due to the increase in crude oil input costs.

From a macroeconomic perspective, these price shifts entail terms-of-trade gains for regions that are net importers of the primary fossil fuels and corresponding terms-of-trade losses for the net exporters of these fuels (Table 2). Regions which are simultaneously net importers of primary fossil fuels and net exporters of refined petrol - namely India and highincome Asia - enjoy the largest terms-of-trade gains, while regions that are on balance net exporters of primary fossil fuels and net importers of refined petrol - namely Oceania, Other East Africa, Central America, and East and West Africasuffer pronounced terms-of-trade losses, as do net importers of both, which are predominantly net importers of refined

\footnotetext{
${ }^{2}$ For example, SSP2 suggests a 2050 population for Africa of 2.0 billion people (Lutz and Samir, 2011) whereas the latest UN projections suggest a population for the region of 2.5 billion by 2050 (UN 2015b), a significant difference.
} 
Table 1 Scenario description

$\begin{array}{ll}\text { Scenario } & \text { Specification }\end{array}$

1a Baseline without climate change (BasenoCC)

1b Baseline with climate change (BaseCC)

2a High fossil fuel price without climate change (HEPnoCC)

$2 \mathrm{~b}$ High fossil fuel price with climate change (HEPCC)

3a High fossil fuel price with increased biofuel use and increased hydropower production without climate change (HEPadapnoCC) $3 \mathrm{~b}$ High fossil fuel price with increased biofuel use and increased hydropower production with climate change (HEPadapCC)

4a Low fossil fuel price without climate change (LEPnoCC) $4 \mathrm{~b}$ Low fossil fuel price with climate change (LEPCC)
Business-as-usual (SSP2) (UNFCCC medium scenario with favorable economic and low population growth -9.1 billion people in 2050)

Business-as-usual (SSP2) combined with high emissions scenario (RCP8.5), HadGEM2-ES

Fossil fuel taxes in GLOBE impacting GDP and price of agricultural chemicals (70 \% tax on coal, $50 \%$ on crude oil; $30 \%$ on natural gas)

Additional changes in IMPACT: gradual reduction of groundwater withdrawal capacity over 2015-2050; by $205020 \%$ lower than baseline to reflect adverse impacts of higher fuel prices on GW pumping

Same as Scenario 2 plus:

Increase in First GEN biofuel demand to compensate for reduced fossil fuel availability, doubled by 2050 (GLOBE and IMPACT)

Gradual, linear increase in hydropower production $(10 \%$ by 2050$)$ with associated $10 \%$ increase in storage and surface water withdrawal capacity

Significant increase in fossil fuel production resulting in a $25 \%$ reduction in world fossil fuel prices compared to the baseline; impacting GDP and agricultural chemical prices petrol (Other South Asia - SA) or net exporters of both, which are predominantly net exporters of crude oil (Middle East and North Africa (MENA), former Soviet Union (FSU), South America). Like Other SA, China, North America (NA), the European Economic Area, and Southern Africa are also net importers of both primary fossil fuels and petrol, but in contrast to Other SA, primary fossil fuels dominate their net fuel imports bill, and thus these regions experience a positive terms-of-trade effect.

Table 2 Terms-of-Trade Effects 2050 (\% deviation from baseline scenario)

\begin{tabular}{|c|c|c|c|c|c|c|}
\hline & \multicolumn{3}{|c|}{ No climate change } & \multicolumn{3}{|c|}{ With climate change } \\
\hline & HEP & HEPadap & LEP & HEP & HEPadap & LEP \\
\hline Oceania & -2.7 & -2.6 & -0.7 & -2.7 & -2.5 & -0.7 \\
\hline China & 0.9 & 0.9 & 2.5 & 0.9 & 0.8 & 2.5 \\
\hline OEastAsia & -1.2 & -1.2 & 1.8 & -1.2 & -1.2 & 1.8 \\
\hline India & 6.6 & 6.6 & 7.4 & 6.5 & 6.5 & 7.4 \\
\hline OSthAsia & -3.9 & -3.9 & 7.0 & -3.9 & -3.9 & 7.0 \\
\hline HIAsia & 5.2 & 5.1 & 2.6 & 5.1 & 5.0 & 2.6 \\
\hline NAmerica & 2.0 & 2.0 & 2.1 & 2.0 & 2.1 & 2.1 \\
\hline CAmerica & -2.2 & -2.2 & 0.8 & -2.1 & -2.1 & 0.8 \\
\hline SAmerica & -1.1 & -0.9 & -0.8 & -1.1 & -0.8 & -0.8 \\
\hline EEA & 1.0 & 1.0 & 1.1 & 1.0 & 1.0 & 1.1 \\
\hline FSU & -2.9 & -2.9 & -8.4 & -2.8 & -2.8 & -8.4 \\
\hline MENA & -6.0 & -6.1 & -10.8 & -5.9 & -6.0 & -10.8 \\
\hline WAfrica & -10.8 & -10.8 & -6.9 & -10.7 & -10.7 & -6.9 \\
\hline EAfrica & -5.1 & -5.1 & -3.3 & -5.1 & -5.1 & -3.3 \\
\hline SAfrica & 1.6 & 1.6 & 1.4 & 1.5 & 1.5 & 1.4 \\
\hline
\end{tabular}

Source: GLOBE
A positive terms-of-trade effect is per se associated with a real income gain for the region, as each unit of aggregate real exports buys more aggregate real imports than before, while a negative terms-of-trade effect means a real income loss as more real exports are required per unit of aggregate imports than before. As shown in Appendix Figure 5 the terms-oftrade impacts are closely associated with impacts on household real income (Fig. 1) passed on to IMPACT after downscaling.

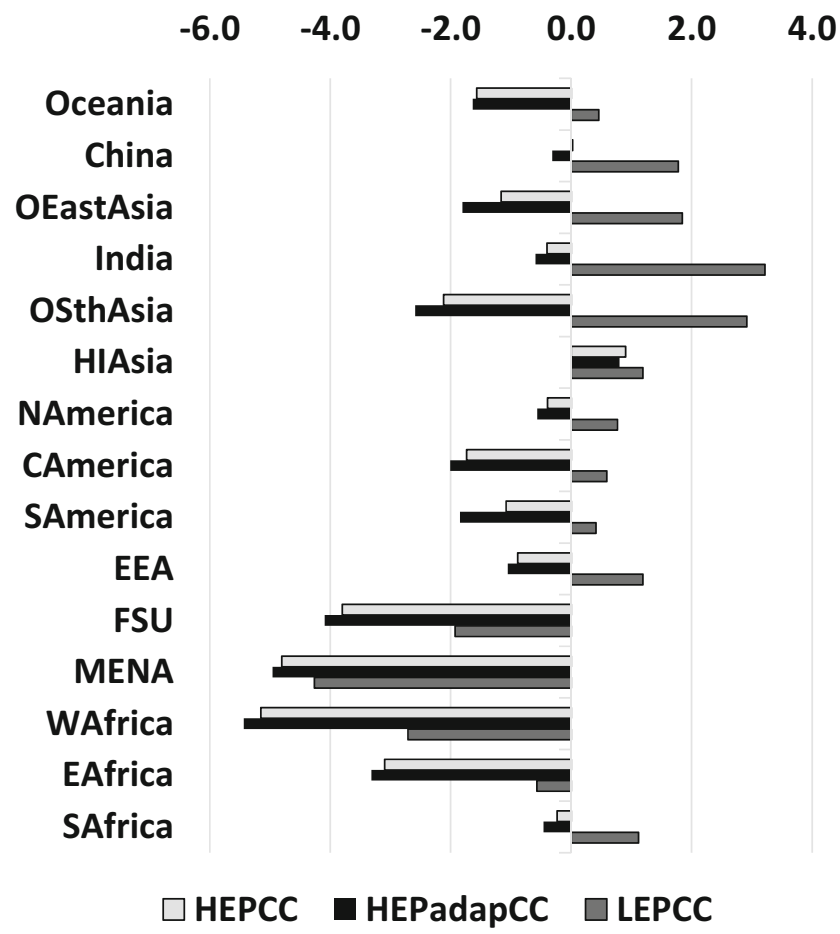

Fig. 1 Impact on real household income (\% deviation from baseline scenario). Source: GLOBE Simulations 2015 
To downscale the real income effects from aggregate GLOBE regions to IMPACT countries, we exploit the fact that, in line with the argument above, the household real income deviations from the baseline simulated are highly correlated with the initial ratios of net fossil fuel exports to GDP, e.g. this ratio explains $90 \%$ of the variation in real income effects for HEP in 2050. We calculate the initial net fossil fuel export ratios for all 135 regions in the fully disaggregated GTAP 8.1 database and use these figures in regressions to downscale the real income effects to GTAP regions. The results from this step are then rescaled so that the weighted average of GTAP region figures for any composite GLOBE region matches with the simulated GLOBE region results. Finally, the GTAP region results are then mapped to IMPACT regions. Appendix Figure 6 depicts the impacts on the prices of chemical goods, which serve as proxies for the impact on fertilizer prices. Regional variations are primarily due to differences in the shares of fossil fuels and electricity costs in the total production cost of chemicals.

Globally, an estimated $40 \%$ of consumptive water use in irrigation stems from groundwater irrigation (Siebert et al. 2010). Groundwater irrigation currently largely depends on fossil fuels, either directly through the use of diesel, for example, in Pakistan (Siddiqi and Wescoat, 2013), or through the use of largely fossil fuel-based electricity (Nelson et al. 2009). As a result, this scenario imposes a gradual decline in the pumping for groundwaterbased irrigation out to 2050 , resulting in a $20 \%$ overall reduction in groundwater pumping capacity in 2050 compared to that in the baseline projection.

Scenario 3 (HEPadap) assumes the same fossil fuel tax increases as in Scenario 2, but introduces a series of mitigating measures to enhance water and food security. To compensate for the reduction in fossil fuel availability, first-generation biofuel feedstock demands by commodity and region rise by $30 \%$ above the levels assumed in the IMPACT baseline scenario and then gradually further up to 2050, such that in 2050, demands are $100 \%$ higher than in the baseline. While the promotion of biofuels as a major measure to mitigate climate change has declined, a significant share of INDCs still included biofuels in their climate change mitigation portfolio.

In addition, hydropower development accelerates slightly over baseline investment levels, adding $10 \%$ additional storage to the overall surface storage portfolio by 2050 ; additional surface storage supports additional (largely gravity-fed) surface water withdrawals for all water uses of a similar magnitude, compensating to some extent for lost groundwater access. As shown in Table 2 and Figs. 1 and Appendix Figure 6, the impacts on macroaggregates and fertilizer prices of the HEPadap scenario are similar to those of the HEP scenario.

Scenario 4 (LEP) assumes that no climate policy will be agreed upon at the 2015 Paris Climate Change Meeting. Therefore, from 2016 onwards, the primary resource extraction in the coal, crude oil, and natural gas sector rises gradually relative to the baseline such that by 2050 , extraction levels are $50 \%$ higher than in the baseline. As a result, world market fossil fuel prices in 2050 are around $25 \%$ lower than in the baseline. The dominant macroeconomic effects are again significant terms-of-trade losses for fossil fuel net export regions mirrored by terms-of-trade gains for the net-importing regions (Table 2). These terms-of-trade effects are the main drivers of the household real income effects depicted in Fig. 1. Not surprisingly, fertilizer prices drop noticeably in all regions relative to the baseline (Appendix Figure 6).

All four scenarios are run with and without climate change, assuming the most aggressive Representative Concentration Pathways (RCPs) from IPCC's 5th Assessment Report (IPCC, 2014), 8.5, which postulates an approximate level of radiative forcing by 2100 of 8.5 watts $/ \mathrm{m}^{2}$, relative to preindustrial values. The scenario was run with the HADGEM2-ES (Jones et al. 2011) - the Hadley Centre's Global Environment Model, version 2 (www.metoffice.gov.uk/ research/modelling-systems/unified-model/climate-models/ hadgem2) as the model formed part of the Coupled Model Intercomparison Project (Taylor et al. 2012).

\section{Results}

Over the coming four decades, population and economic growth and urbanization is shifting diets toward increased demand for livestock products as well as fruits and vegetables, sugars, and oils. Demand for cereals increases both as food as some countries and regions shift out of roots and tubers and into cereals while others reduce per capita consumption of some cereals and, importantly, as livestock feed, particularly maize. According to our results, per capita demand for livestock products is rapidly growing in the group of developing countries. Demand is projected to almost triple in SA and to more than double in sub-Saharan Africa (SSA). In the Middle East and North Africa (MENA), demand is expected to grow by close to $50 \%$ and in the East Asia and Pacific (EAP) region by more than $40 \%$ during 2010-2050 under a no climate change scenario, while in North America (NA) and Europe, demand is expected to barely change.

In response, globally, production of cereals, meats, and roots and tubers is expected to increase by 51,67 , and $51 \%$, respectively (Table 3); demand for fruits and vegetables and pulses is expected to grow even faster, by 85 and $84 \%$, respectively, under a no climate change scenario. However, demand for food products will outpace food production growth, putting long-term upward pressure on global, agricultural commodity prices. Prices for most commodities will increase in the range of $20 \%$ with particular large increases expected for the price of maize at $32 \%$ under the no climate change baseline (Table 4). Climate change has an overall 
Table 3 Changes in global production of agricultural commodities (in '000 tons), 2010 and 2050, alternative fossil fuel scenarios

\begin{tabular}{|c|c|c|c|c|c|c|c|c|c|}
\hline \multirow[t]{2}{*}{ Commodity groups } & \multirow{2}{*}{$\begin{array}{l}\text { Base year } \\
\text { Million mt } \\
2010\end{array}$} & \multicolumn{4}{|c|}{ No climate change (2050) } & \multicolumn{4}{|c|}{ With climate change (2050) } \\
\hline & & $\begin{array}{l}\text { mmt } \\
\text { Base }\end{array}$ & HEP & $\begin{array}{l}\% \\
\text { HEPadap }\end{array}$ & LEP & $\begin{array}{l}\text { mmt } \\
\text { Base }\end{array}$ & HEP & $\begin{array}{l}\% \\
\text { HEPadap }\end{array}$ & LEP \\
\hline Meat products & 274 & 459 & 0.01 & 0.25 & 0.01 & 455 & 0.04 & 0.28 & 0.00 \\
\hline Cereals & 2158 & 3261 & 0.11 & 1.06 & 0.06 & 3014 & 0.11 & 0.90 & 0.01 \\
\hline Fruits and vegetables & 1592 & 2948 & $(0.07)$ & $(0.27)$ & 0.03 & 2884 & $(0.08)$ & $(0.30)$ & 0.01 \\
\hline Pulses & 66 & 121 & $(0.02)$ & $(0.46)$ & 0.04 & 116 & 0.02 & $(0.39)$ & 0.01 \\
\hline Roots and tubers & 778 & 1176 & $(0.04)$ & 0.14 & 0.03 & 1123 & $(0.07)$ & 0.17 & $(0.02)$ \\
\hline
\end{tabular}

Numbers in round brackets indicate negative values. Source: IMPACT3 Simulations 2015

detrimental impact on food security, increasing prices for cereals by $34 \%$ in 2050 compared to the no climate change scenario, with the largest projected increase for maize by $59 \%$, as a result of both adverse impacts from climate change on crop production and the decline in household income as a result of climate change on all sectors of the economy. Such price increases have direct adverse food security impacts for the poorest consumers. Prices for roots and tubers, which are important staples in SSA and parts of Latin America, are projected to increase by $14 \%$. Price increases between a climate change and a no climate change scenario are somewhat lower for livestock products, in part because these are simulated in response to changes in livestock feed prices and lower household incomes rather than direct adverse impacts from climate change on animal numbers (Table 4).

Average calorie availability in the group of developing countries is projected to increase by 473 cal per capita a day, to 3158 cal by 2050 with the largest increases expected in SSA, EAP, and SA. Under a climate change alternative, the increase would be 120 cal lower. Importantly, despite the relatively low population growth and the relatively high economic growth, and business-as-usual investment in agricultural $\mathrm{R} \& \mathrm{D}$, the number of people at risk of hunger estimated under the baseline run remains substantial in 2050, with 452 million people projected at risk of hunger in the no climate change scenario and 545 million people at risk of hunger estimated under the climate change scenario (Fig. 2). These numbers constitute a substantial decline over the 2010 estimate of 922 million people at risk of hunger, but remain unacceptably high. $^{3}$

Energy access continues to improve, still driven, to a large extent by fossil fuels, but with considerable growth in renewables. On the water side, approximately $85 \%$ of freshwater consumption (and $60 \%$ of freshwater withdrawals) were used for irrigation in 2010 globally. This share is projected to decline only slowly, to $81 \%$ by 2050 under climate change (BaseCC) (and to $80 \%$ under the no climate change scenario

\footnotetext{
${ }^{3}$ For information on how the number of population at risk of hunger is calculated in this study, please refer to Robinson et al. (2015).
}

BasenoCC), balancing more rapidly growing demand for water in the domestic and urban sectors with growing evapotranspiration demands from increased food production needs and climate change. Between 2010 and 2050, the population at risk of water stress - defined as the population in basin areas where water withdrawals exceed $40 \%$ of available water resources (Alcamo et al. 2003; Oki and Kanae, 2006) - is expected to grow from 2.96 billion ( $43 \%$ of the global population) to 4.46 billion people (50\% of the projected SSP2 global population) under the climate change scenario. Almost the entire population in the MENA region will live in areas with high water stress as will high shares of the South Asian population. Even in NA, Europe and the FSU severe water stress can affect up to half of the residents. Only SSA will continue to face relatively low water stress (Fig. 3).

In 2010 , about $13 \%$ of water demands across the agriculture, domestic, and industrial sectors could not be met either due to the lack of water availability or due to lack of investment or access (using the withdrawal concept). By 2050, the overall share of unmet water demands does not change significantly, but large shifts are projected across regions. Over the period from 2010 to 2050, the share of unmet water demands is expected to almost double in SSA, to $17 \%$, and to almost triple in NA, to $7 \%$ under the BaseCC scenario (Fig. 4).

\section{Impact of changes in fossil fuel prices on food and water}

What are the impacts of changes in energy prices on food and water security? Overall, higher energy prices as described in HEPCC adversely affect GDP, with the exception of highincome Asia (Fig. 1) and thus the capacity of national populations to afford food products. This dampens food demand and prices slightly (Table 4) with small feedback effects increasing production. Higher fertilizer prices and lower access to groundwater pumping increase food prices, but the key impacts are through lack of household income to purchase food. Overall, price levels under both higher fossil fuel price scenarios (HEPnoCC and HEPCC) are slightly higher compared to the baseline values for both cereals and livestock 
Table 4 Changes in global prices of agricultural commodities, 2010 and 2050, alternative fossil fuel scenarios

\begin{tabular}{|c|c|c|c|c|c|c|c|c|c|}
\hline \multirow[t]{3}{*}{ Commodity groups } & Base year & \multicolumn{4}{|c|}{ No Climate Change (2050) } & \multicolumn{4}{|c|}{ With Climate Change (2050) } \\
\hline & \multicolumn{2}{|l|}{$\mathrm{US} \$ / \mathrm{mt}$} & \multicolumn{3}{|l|}{$\%$} & \multirow{2}{*}{$\begin{array}{l}\text { US\$/mt } \\
\text { Base }\end{array}$} & \multicolumn{3}{|l|}{$\%$} \\
\hline & 2010 & Base & HEP & HEP adap & LEP & & HEP & HEPadap & LEP \\
\hline All meat products & 2315 & 2785 & 0.32 & $(0.43)$ & $(0.04)$ & 2971 & 0.43 & $(0.29)$ & $(0.02)$ \\
\hline Beef & 3228 & 3703 & 0.28 & 0.19 & $(0.03)$ & 3889 & 0.37 & 0.34 & $(0.01)$ \\
\hline Pork & 2077 & 2666 & 0.29 & $(0.35)$ & $(0.04)$ & 2847 & 0.40 & $(0.25)$ & $(0.01)$ \\
\hline Poultry & 1566 & 1940 & 0.44 & $(1.41)$ & $(0.06)$ & 2132 & 0.61 & $(1.21)$ & $(0.02)$ \\
\hline All cereals & 215 & 258 & 1.48 & 3.77 & $(0.14)$ & 344 & 1.65 & 4.29 & $(0.03)$ \\
\hline Maize & 146 & 193 & 0.75 & 4.34 & $(0.04)$ & 307 & 0.93 & 3.20 & $(0.03)$ \\
\hline Rice & 358 & 452 & 1.80 & 3.03 & $(0.19)$ & 596 & 1.87 & 3.27 & 0.01 \\
\hline Wheat & 219 & 265 & 2.11 & 5.01 & $(0.18)$ & 322 & 2.39 & 7.03 & $(0.05)$ \\
\hline Fruits and vegetables & 868 & 1092 & 0.73 & 1.87 & $(0.13)$ & 1234 & 0.83 & 2.07 & $(0.03)$ \\
\hline Pulses & 943 & 1065 & 0.66 & 2.10 & $(0.13)$ & 1272 & 0.80 & 2.34 & $(0.03)$ \\
\hline Roots and tubers & 341 & 430 & 0.54 & 1.20 & $(0.10)$ & 490 & 0.71 & 1.42 & 0.07 \\
\hline Cassava & 117 & 150 & 0.35 & 4.00 & $(0.07)$ & 164 & 0.61 & 4.40 & 0.13 \\
\hline Potato & 268 & 324 & 0.63 & 1.69 & $(0.14)$ & 405 & 0.72 & 1.88 & $(0.04)$ \\
\hline
\end{tabular}

Numbers in round brackets indicate negative values. Source: IMPACT3 Simulations 2015

products. The pressure on prices is slightly larger under the climate change scenario. There is a particular upward pressure on prices for wheat and also rice (Table 4).

As a result of slightly lower income growth and slightly higher prices for staples, which globally account for around $40 \%$ of calories in 2010, the population at risk of hunger barely changes globally, in response to the energy price shock. On balance, the number of people at risk of hunger increases slightly more under the climate change scenario. Increases do vary by region, with the largest increase in SA with five million people (Fig. 2).

Small changes in the demand for and supply of food products as a result of the fossil fuel price increase also impacts on the calculated water security indicators. In 2050, the population at risk of severe water stress declines by $1.3 \%$ as a result of lower agricultural activities and the decline in access to groundwater under the climate change scenario and by $0.6 \%$ under the energy price shock without climate change (Fig. 3). Differences are small as water stress is defined as withdrawal exceeding $40 \%$ of water availability: Once a basin already belongs to the 'stressed' category, a further increase in water withdrawals would not affect its water scarcity category and for a basin below the category, a significant increase in withdrawals would be needed to move it above the $40 \%$ mark. At the same time, the share of unmet water demands increases significantly in those regions that depend on groundwater as a main source for domestic, industrial, and irrigation supplies with counter-vailing effects from reduced irrigation activities in some regions. The share of unmet water withdrawal demands tampered by changes in water supply increases by $20 \%$ globally under both HEPCC and HEPnoCC compared to their respective baselines. Unmet demands increase particularly in NA, by $43 \%$, and in SA, by $36 \%$. The increase is much smaller in SSA, at $13 \%$. (Fig. 4).

When various measures to compensate for increased fossil fuel prices are introduced (HEPadap with and without climate change scenario), then household incomes in key developing
Fig. 2 Number of people at risk of hunger, 2050, alternative energy price scenarios (million people). Source: IFPRI Impact Simulations

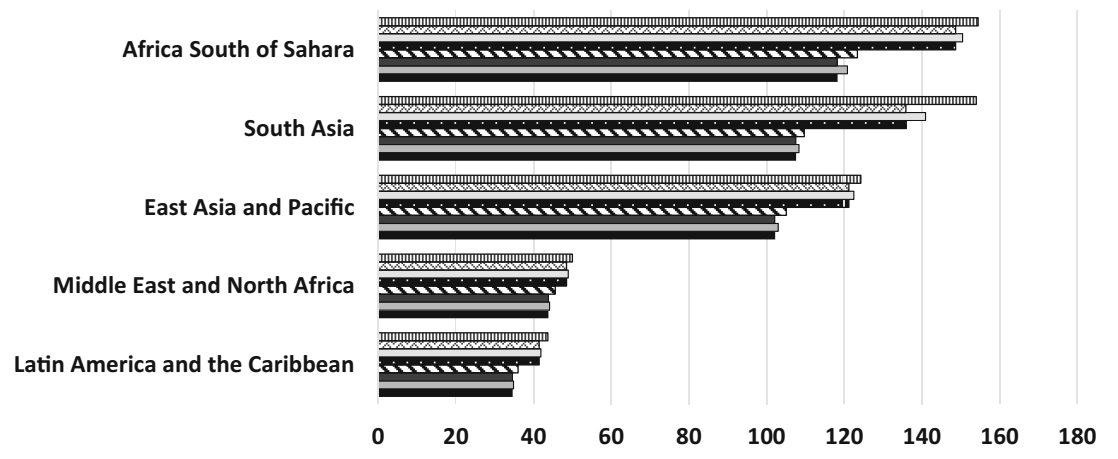

血 HEPadapCC $⿴ 囗 ⿱ 一 一)$ LEPCC $\square$ HEPCC $\square$ BaseCC $\triangle$ HEPadapnoCC $\square$ LEPnoCC $\square$ HEPnoCC $\square$ BasenoCC 
Fig. 3 Population under water stress (withdrawal of $40 \%$ or more of internal renewable resources). Source: IFPRI Impact Simulations

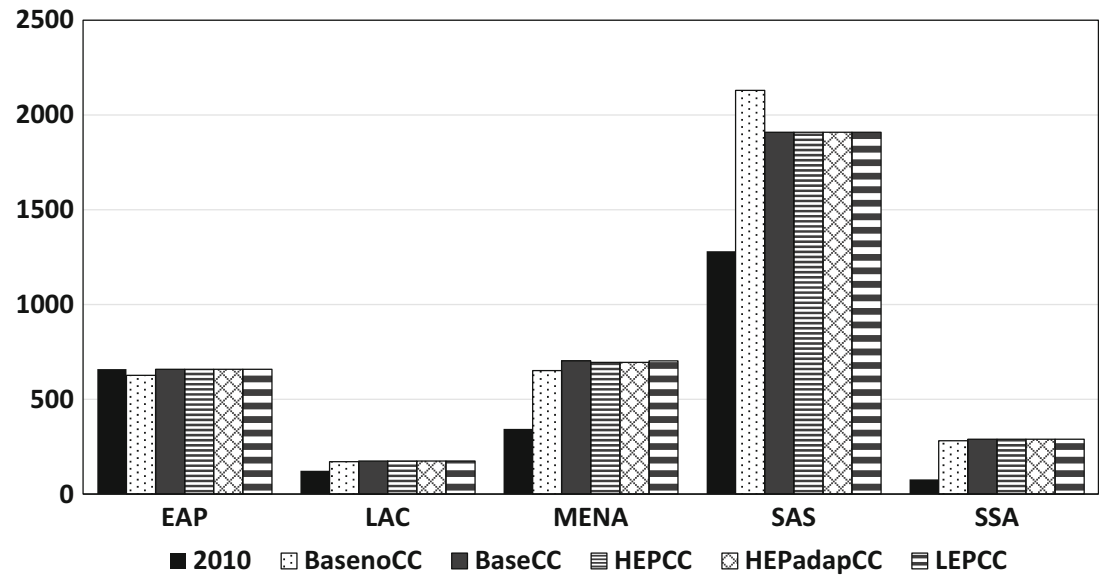

regions decline slightly further. The reason is due to the energy source alternatives considered. The additional biofuel demand using first-generation technologies in HEPadap raises nominal agricultural prices (directly for the feedstock commodities and indirectly for other agricultural commodities via upward pressure on land rents) with ripple-on effects for processed foods. This reduces the real purchasing power of household nominal income or-stated equivalently - real wages and real returns to other non-land production factors drop slightly more than under the HEP scenario. As a result of the increased use of biofuels for energy production, global staple food prices increase compared to the baseline scenario and also compared to HEP. After 2025, second-generation biofuel feedstock is expected to take on a larger role in global energy supplies. As a result of the lower household incomes, the relative price of chemicals to the price of the consumption basket drops-but the net effect is small as additional demand for chemicals in the production of biofuels works in the opposite direction. The increased use of surface water through increased reservoir storage, on the other hand, improves water-for-food outcomes slightly but not sufficient to compensate for the declining food security situation caused by biofuel demand.

Under HEPadapCC, global prices for livestock decline $0.7 \%$ compared to the HEPCC scenario, while prices for cereals increase by close to $3 \%$ as a result of the demand for cereals as biofuel feedstock. Prices for cassava increase by $4 \%$ for the same reason (Table 4 ). Across the group of developing countries, per capita food demand for all commodities declines slightly compared to the HEPCC scenario, again due to the competition with biofuel demand and the limited benefit from surface storage changes on food production and prices. Calorie availability across the group of developing countries declines by $0.7 \%$ compared to the HEPCC scenario, and the number of people at risk of hunger grows globally by a further 23 million compared to the HEPCC scenario to 578 million people. Increases in the number of people at risk of hunger are projected to be largest in SA, an increase by 13 million people, followed by Africa south of the Sahara, with 4 million people (Fig. 2). The number of people at risk of severe water stress barely changes. The share of unmet water demands declines by 1.2 percentage points under this scenario compared to HEPCC, presumably as a result of continued declines in food demand and small increases in surface water storage; declines are largest in NA, MENA, and SSA (Fig. 4).

The final scenario, LEP, assessed the impacts of an increase in fossil fuel availability and concomitant lower energy prices on water and food security - a scenario that we have been
Fig. 4 Share of unmet water demands, 2010 and projected 2050 , alternative scenarios with climate change. Source: IFPRI Impact Simulations

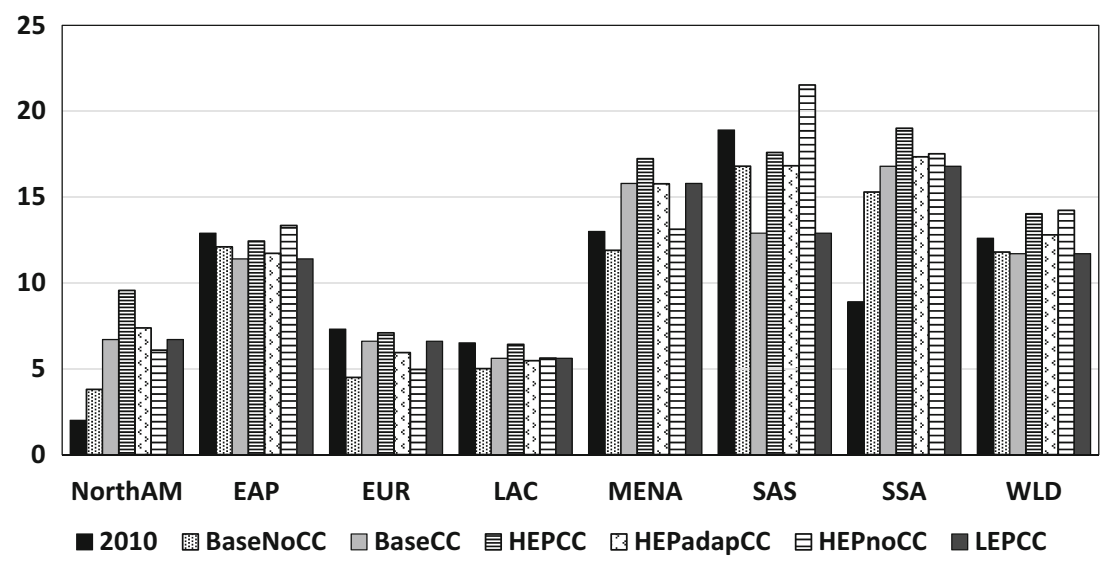


seeing over the last few years. As a corollary to the HEP scenario, increased availability of fossil fuels and thus lower energy prices benefit those regions that are net importers of fossil fuels due to the improvement in their terms of trade while net exporters suffer a corresponding aggregate real income loss. Although energy prices faced by households drop in all regions - which per se enhances the capacity of national populations to afford food products - the adverse terms-oftrade effect dominates this real purchasing power gain in the net fuel export regions (Fig. 1). Under the LEPCC scenario, the combination of higher household incomes and lower agricultural chemical prices increases food demand, but not sufficiently to increase food prices compared to the BaseCC scenario. Global prices for cereals and livestock products decline slightly (Table 4). The overall slightly lower food prices reduce the population at risk of hunger by 0.1 million in SA and by smaller amounts elsewhere. Similarly to the other scenarios, outcomes for water security vary by region, but changes are much smaller compared to the changes experienced under the HEP and HEPadap scenarios (Fig. 4).

\section{Conclusion}

This article describes the complex relationship between energy price changes and outcomes for food and water security using two global modeling frameworks: the global CGE model GLOBE and the partial equilibrium model IMPACT assessing various energy price pathways under a climate change and a no climate change scenario out to 2050 . We find that higher fossil fuel prices due to a carbon tax, for example, reduce household income, particularly of countries that are net exporters of fossil fuels or net importers of refined petrol. Carbon taxes geared toward mitigating climate change slightly change food production levels, but do not significantly affect food prices and food security. We thus confirm the earlier analysis by Gohin and Chantret (2010) who also find that the direct cost-push effect of higher energy prices on food prices can be dominated by macroeconomic income effects. When energy prices do not increase under upward pressure from economic growth but as a result of energy supply shocks.

However, substantially expanding biofuel production to increase energy availability increases the number of food-insecure people. To the extent that the reduction in fossil fuel use due to carbon taxes lessens climate change, these taxes can improve food security substantially. Carbon taxes are one important avenue supported by the Paris Agreement to shift capital flows toward climate mitigation. However, it is not clear if and when such a measure would be jointly supported by the major emitters.

The linked modelling framework facilitates a quantitative analysis of the wider implications of agricultural sector scenario projections generated by a detailed agricultural economy model (IMPACT) by taking systematic account of linkages between agriculture and the rest of the economy and allows a rigorous theory-grounded general equilibrium welfare analysis of shocks to agriculture. Conversely, the linked approach supports a detailed analysis of the effects of shocks that initially hit non-agricultural sectors on agricultural variables and water security.

However, as this analysis chiefly relies on economic models, we cannot relate our changes in fossil fuel use modeled with temperature targets. The approach currently does not include a carbon-cycle module to calculate GHG emissions resulting from economic activity. We also only focus on a subset of emission reduction options that are being considered by countries. For example, other important measures that are proposed as part of the INDCs but which we do not assess include direct investments in energy efficiency improvement, changes in land use change, changes in power transmission, and various changes in components of renewable energy sources. More research is needed to assess the implications of other drivers on energy prices on overall water and food security given the continued close linkages of energy with water and food outcomes as well as the continued uncertainty of energy developments out into the future.

\section{Appendix 1}

Table 5 GLOBE sector aggregation

\begin{tabular}{lll}
\hline Short code & Description & GTAP sector code \\
\hline Rice & Rice & pdr,pcr \\
Wheat & Wheat & wht \\
OCereals & Other cereals & gro \\
Oilseeds & Oil seeds & osd \\
SugarCane & Sugar cane and beet & c_b \\
OCrops & Other crops & ocr,pfb \\
Cattle & Bovine cattle, sheep and & ctl \\
& goats, horses & \\
OLvstkPrd & Other livestock products & wol,oap,rmk \\
VegOils & Vegetable oils and fats & vol \\
Sugar & Sugar & sgr \\
OPrFood & Other processed food & cmt,omt,mil,ofd,b_t \\
Coal & Coal & coa \\
Oil & Crude oil & oil \\
NatGas & Natural gas & gas,gdt \\
ONatRes & Other natural resources & omn,frs,fsh \\
LgtManuf & Light manufacturing & tex,wap,lea,lum,ppp,omf \\
Petrol & Refined petrols & p_c \\
Chemics & Chemicals, rubber and & crp \\
& plastics & nmm,i_s,nfm,fmp,mvh,otn,ele,omc \\
OManuf & Other manufacturing & ely \\
Electricity & Electricity &
\end{tabular}


Table 5 (continued)

\begin{tabular}{lll}
\hline Short code & Description & GTAP sector code \\
\hline Water & Water distribution & wtr \\
Constrc & Construction & cns \\
TrdTrns & Trade and transport services & trd,otp,wtp,atp \\
OServic & Other services & cmn,ofi,isr,obs,ros,osg,dwe \\
& &
\end{tabular}

Table 6 Region aggregation

\begin{tabular}{ll}
\hline Short code & Description \\
\hline Oceania & Australia, New Zealand, and Other Oceania \\
China & China \\
OEastAsia & Other East Asia \\
India & India \\
OSthAsia & Other South Asia \\
HIAsia & High-income Asia \\
NAmerica & North America \\
CAmerica & Central America and Caribbean \\
SAmerica & South America \\
EEA & European Economic Area \\
FSU & Former Soviet Union \\
MENA & Middle East and North Africa \\
WAfrica & West Africa \\
EAfrica & East and Central Africa \\
SAfrica & Southern Africa \\
\hline
\end{tabular}

Source: GLOBE

Table 7 Percentage change in fossil fuel use in electricity sector 2050 relative to 2050 baseline

\begin{tabular}{llll}
\hline & cCoal & cNatGas & cPetrol \\
\hline Oceania & -13.9 & -10.2 & -4.3 \\
China & -10.4 & -23.6 & -3.5 \\
OEastAsia & -16.7 & -12.1 & -7.1 \\
India & -11.2 & -14.7 & -5.5 \\
OSthAsia & -25.1 & -15.3 & -13.9 \\
HIAsia & -17.2 & -8.4 & -6.9 \\
NAmerica & -14.1 & -13.4 & -5.8 \\
CAmerica & -17 & -15.3 & -7.3 \\
SAmerica & -16.9 & -14.7 & -7.2 \\
EEA & -15.7 & -6.2 & -6.4 \\
FSU & -15.7 & -12.1 & -11.4 \\
MENA & -17.1 & -14.1 & -12.1 \\
WAfrica & -26.9 & -16.5 & -12.7 \\
EAfrica & -15.6 & -16.1 & -10 \\
SAfrica & -14.9 & -13.1 & -5.5 \\
\hline
\end{tabular}

Source: GLOBE

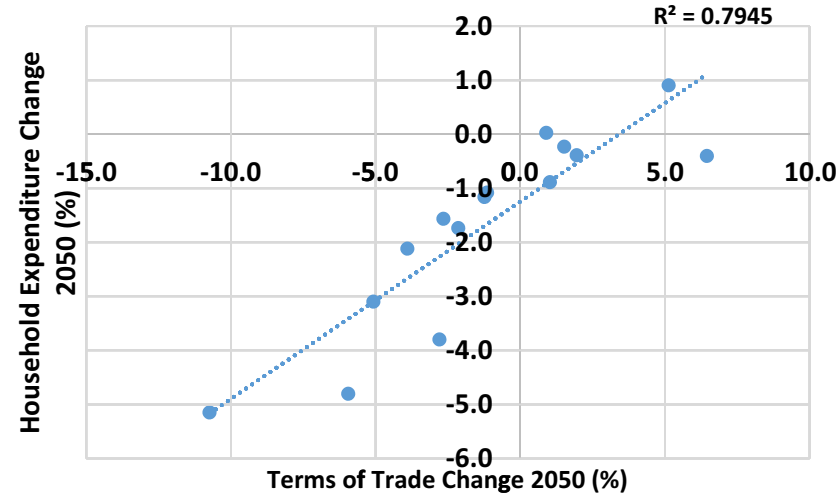

Fig. 5 Correlation between terms-of-trade and household income effectsHEP Scenario (\% Deviations from Baseline by Region 2050). Source: Based on GLOBE data

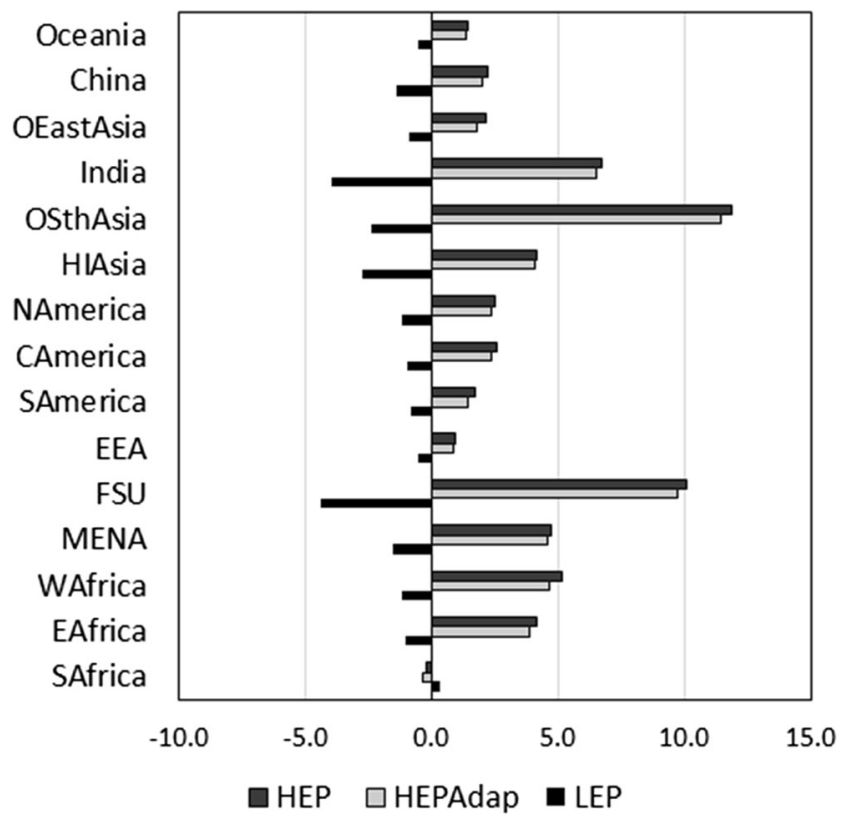

Fig. 6 Impact on price of chemicals 2050 (\% deviation from baseline scenario). Source: based on GLOBE data

Acknowledgments This study was implemented with financial support from the CGIAR Research Program on Water, Land and Ecosystems (WLE) and the Federal Ministry for Economic Cooperation and Development, Germany.

Open Access This article is distributed under the terms of the Creative Commons Attribution 4.0 International License (http:// creativecommons.org/licenses/by/4.0/), which permits unrestricted use, distribution, and reproduction in any medium, provided you give appropriate credit to the original author(s) and the source, provide a link to the Creative Commons license, and indicate if changes were made.

\section{References}

Alcamo J, Döll P, Henrichs T, Kaspar K, Lehner B, Rösch T, Siebert S (2003) Global estimates of water withdrawals and availability under current and future 'business-as-usual' conditions. Hydrol Sci J 48(3):339-348 
Dodder RS, Elobeid A, Johnson TL, Kaplan PO, Kurkalova LA, Secchi S, Tokgoz S (2011) Environmental impacts of emerging biomass feedstock markets: energy, agriculture and the farmers. Center for Agricultural and Rural Development. Accessed at http://www.card. iastate.edu/publications/dbs/pdffiles/11wp526.pdf

Gohin A, Chantret F (2010) The long-run impact of energy prices on world agricultural markets: the role of macro-economic linkages. Energy Policy 38:333-339

Government Office for Science (2011) Food system scenarios and modelling. Foresight Project Global Food and Farming Futures Synthesis Report C4. Government Office for Science, London

Hertel TW, Tyner TW, Birur DK (2010) The global impacts of biofuel mandates. Energy J 31(1):75-100

Hertel T, Steinbuks J, Baldos U (2013) Competition for land in the global bioeconomy. Agri Econ 00:1-10

IEA (International Energy Agency), 2015. Accessed at https://www. iea.org/publications/freepublications/publication/ WEO2015SpecialReportonEnergyandClimateChange.pdf

IEA (2012) Energy Technology Perspectives 2012: Pathways to a Clean Energy System, International Energy Agency (IEA). France, Paris

IPCC (2014) Climate Change 2014: Synthesis Report. Contribution of Working Groups I. II and III to the Fifth Assessment Report of the Intergovernmental Panel on Climate Change, IPCC, Geneva, Switzerland, $151 \mathrm{pp}$

Jones CD, et al. (2011) The HadGEM2-ES implementation of CMIP5 centennial simulations. Geosci Model Dev 4:543-570.

Lutz W, Samir KC (2011) Global human capital: integrating education and population. Science 333(6042):587-592. doi:10.1126/science. 1206964

McDonald S, Thierfelder K, Robinson S (2007) Globe: a SAM based global CGE model using GTAP data, USNA Working Paper 14. US Naval Academy, Annapolis

Narayanan B, Aguiar A, McDougall RA (2012) Global trade, assistance, and production: the GTAP 8 Data Base. In: Center for Global Trade Analysis. Purdue University, West Lafayette

Nelson GC, Robertson R, Msangi S, Zhu T, Liao X, Jawahar P (2009) Greenhouse gas mitigation issues for Indian agriculture. IFPRI Discussion Paper No. 900. http://ebrary.ifpri.org/utils/getfile/ collection/p15738coll2/id/23497/filename/23498.pdf

NREL, MM Hand, S Baldwin, E DeMeo, J Reilly, D Arent, G Porro, T Mai, Meshek M, Sandor D (2012) Renewable Electricity Futures Study. Hand,. eds. 4 vols. National Renewable Energy Laboratory (NREL).

Oki T, Kanae S (2006) Global hydrological cycles and world water resources,'. Science 313(5790):1068-1072. doi:10.1126/science. 1128845
O'Neill BC et al. (2015) The roads ahead: narratives for shared socioeconomic pathways describing world futures in the 21st century. Global Environ Change. doi:10.1016/j.gloenvcha.2015.01.004

O’Neill BC, Kriegler E, Riahi K, Ebi KL, Hallegatte S, Carter TR, Mathur R, van Vuuren VP (2014) A new scenario framework for climate change research: the concept of shared socioeconomic pathways. Clim Chang 122:387-400

Ringler C, Bhaduri A, Lawford R (2013) The nexus across water, energy, land and food (WELF): potential for improved resource use efficiency? Curr Opin Environ Sustain 5(6):617-624

Robinson S, Mason-D'Croz D, Islam S, Sulser TB, Robertson R, Zhu T, Gueneau A, Pitois G, Rosegrant M (2015) The International Model for Policy Analysis of Agricultural Commodities and Trade (IMPACT): model description for Version 3. IFPRI Discussion Paper 1483. Washington, DC: International Food Policy Research Institute. http://ebrary.ifpri.org/cdm/ref/collection/p15738coll2/id/ 129825

Rosegrant MW (2008) Biofuels and grain prices: impacts and policy responses. Testimony for the U.S. Senate Committee on Homeland Security and Governmental Affairs. Accessed at http://ebrary.ifpri.org/utils/getfile/collection/p15738coll2/id/ 10350/filename/10351.pdf

Rosegrant MW, Zhu T, Msangi S, Sulser T (2008) Global scenarios for biofuels: impacts and implications. Revi Agri Econ 30(3):495-505

Siddiqi A, Wescoat JL (2013) Energy use in large-scale irrigated agriculture in the Punjab province of Pakistan. Water Inter 38(5):571-586

Siebert S, Burke J, Faures JM, Frenken K, Hoogeveen J, Doell P, Portman FT (2010) Groundwater use for irrigation - a global inventory. Hydrol Earth Syst Sci 14:1863-1880

Steinbuks J, Hertel TW (2013) Energy prices will play an important role in determining global land use in the twenty first century. Environ Res Lett 8:1-10

Taylor KE, Stouffer RJ, Meehl GA (2012) An overview of Cmip5 and the experiment design. Bull Am Meteorol Soc 93(4):485-449

UN (United Nations) (2015a). Transforming our world: the 2030 Agenda for Sustainable Development. Accessed at http://www.un.org/ga/ search/view_doc.asp?symbol=A/RES/70/1\&Lang=E.

UN (2015b) Department of Economic and Social Affairs, Population Division. World Population Prospects: The 2015 Revision, DVD Edition.

Willenbockel D (2012) Extreme weather events and crop price spikes in a changing climate: illustrative global simulation scenarios. Oxfam Research Reports, Oxford: Oxfam. 